\title{
STUDY OF ELEMENTARY COMPOSITION AND STRUCTURAL CHARACTERISTICS OF HIGH-ASH BROWN COAL OF ANGREN DEPOSIT
}

\author{
Rakhimjan Babakhodjaev ${ }^{1 *}$, Nazim Tashbaev ${ }^{1}$, Jonreed Mirzaev ${ }^{1}$, Abdumalik Karimov ${ }^{1}$. \\ ${ }^{1}$ Tashkent State Technical University named after Islam Karimov, Heat power engineering and nuclear power plants Depertment, \\ Universitetskaya 2, Tashkent, Uzbekistan
}

\begin{abstract}
Annotation. The results of the study of the composition and characteristics of high-ash brown coal of the Angren deposit, used in the power industry of the Republic of Uzbekistan are presented. A feature of this coal is the presence in the composition of the fuel of various clay rocks that fall during mechanized mining from the surrounding rocks. Dependencies have been determined showing the effect of the composition of the fuel and the parameters of its characteristics on mechanical, chemical and thermal processes, as well as on the chemical composition of brown coal ash.
\end{abstract}

\section{Introduction}

In the fuel balance of the republic, the share of brown coal in question is about 5\%. The Angren and NovoAngren thermal power plants are coal-fired. To carry out research work to improve the quality of the coal in question, it is necessary to carry out research work to determine its composition and characteristics using modern methods and laboratory equipment.

\section{Main part}

During the metamorphism of coals, a structural and molecular change in organic matter occurs, accompanied by an increase in the relative content of carbon, a decrease in oxygen and the release of volatiles. At the middle stages of coalification, the hydrogen content, heat of combustion, hardness, density, brittleness, optical, electrical and other physical properties of coals change [1]. It should be noted that not only coals of different types differ significantly from each other in characteristics, but coals of the same grade often have different quality indicators. The characteristics of coals mainly depend on the conditions of formation and are necessary for marking and determining the appropriate conditions for their use. The main characteristics of the brown coal under consideration include the following, reflecting its quality, parameters of the heat of combustion, humidity, ash content, sulfur content, the yield of volatile substances and others, where the main indicator is the heat of combustion. The release of volatiles is no more than $40 \%$, the highest heat of combustion is less than 24 MJ / kg. Mineral impurities accompanying in the composition of coal are divided into: primary constituting $0.5 \%$ of dry mass; secondary - accumulated in the bedding layer, carried by water and wind; tertiary
- falling during mining from the surrounding rocks. Grinding capacity $(\mathrm{Klo}=1.9 \ldots 2.1)$ and abrasiveness $(\mathrm{Kabr}=1.1)$ of coal strongly affect the rate of wear and energy consumption of the station's grinding units. Sulfur pyrite $\left(\mathrm{FeS}_{2}\right)$ reduces mill productivity, which increases the specific power consumption for grinding and the rate of equipment wear and corrosion of the tail surfaces of boilers, and also reduces the ash melting temperature and leads to slagging of heating surfaces [2, 3]. Mechanical under burning is influenced by the quality of coal dust, which is estimated by the integral curve obtained by sieving through a set of sieves with mesh sizes of 90, 200, 500 and 1000 microns. For brown coals, the remains of coal particles on sieves with appropriate mesh sizes must correspond to: $\mathrm{R}_{90}=38 \ldots$ $55 \%, R_{200}=18 \ldots 40 \%, R_{1000}=0,6 \ldots 1,6 \%$. This curve also allows you to determine the value of the coefficient of dust polydispersity according to the equation [4]:

$\mathrm{n}=\left(\lg \ln \left(100 / \mathrm{R}_{200}\right)-\lg \ln \left(100 / \mathrm{R}_{90}\right)\right) / \lg 200-\lg 90$

The value of equation (1) tends to an infinitely large number for monodisperse dust. The bulk density of brown coal is $500-700 \mathrm{~kg} / \mathrm{m}^{3}$, and after compaction has a value equal to $800-900 \mathrm{~kg} / \mathrm{m}^{3}$. Looseness is characterized by the angle of repose, the coefficient of mobility, initial shear stress, adhesion and cohesion. The value of the fuel is determined through the calorific value, heat output, ash content, volatile matter yield, coke and by the cost of preparing the fuel for combustion. The main fuel elements in brown coals are carbon, hydrogen and a sulfur compound in the form of iron pyrite. The combustion of $1 \mathrm{~kg}$ of gaseous hydrogen releases 4,2 times more heat than the combustion of $1 \mathrm{~kg}$ of carbon. Pyrite burns with the formation of sulfur dioxide and iron oxides with the release of about 3100

\footnotetext{
*Corresponding author: rachimjan@mail.ru
} 
kcal per $1 \mathrm{~kg}$ of sulfur according to the following reaction $[3,5]$ :

$$
4 \mathrm{FeS}_{2}+110_{2}=2 \mathrm{Fe}_{2} \mathrm{O}_{2}+8 \mathrm{SO}_{2}
$$

The composition of the test coal. Oxygen, minerals and ballast reduce its calorific value and heat output. Below are the properties of high-ash brown coal of the Angren deposit and its ash (Table 1 and Table 2), determined by the method of laboratory research at the Angren thermal station. Coal contains from 2 to $22 \%$ clay materials, consisting of $40-68 \%$ of minerals: silica $\mathrm{SiO}_{2}$, alumina $\mathrm{Al}_{2} \mathrm{O}_{3}$, clay, sulfides, mainly $\mathrm{FeS}_{2}$, carbonates and sulfates in the form of $\mathrm{CaCO}_{3}, \mathrm{MgCO}_{3}$, $\mathrm{FeCO}_{3}, \mathrm{CaSO}_{4}, \mathrm{MgSO}_{4}$, dioxides metals, phosphates, chlorides, alkali metal salts. Table 1. Elemental composition and structural characteristics of the studied samples of brown coal from the Angren deposit by production sites.

Table 1. Elemental composition and structural characteristics of the studied samples of high-ash brown coal from the Angren deposit (by production sites).

\begin{tabular}{|c|c|c|c|}
\hline Coal mines & $\begin{array}{c}\text { Angren - } \\
1\end{array}$ & $\begin{array}{c}\text { Angren - } \\
2\end{array}$ & Apartak \\
\hline $\mathbf{C ,} \%$ & 68,4 & 69,6 & 68,5 \\
\hline $\mathbf{H , ~ \%}$ & 4,1 & 4,2 & 4,5 \\
\hline $\mathbf{N}, \mathbf{\%}$ & 2,1 & 1,9 & 2,1 \\
\hline $\mathbf{S , \%}$ & 4,3 & 4,4 & 4,2 \\
\hline $\mathbf{O}, \mathbf{\%}$ & 21,2 & 19,7 & 20,7 \\
\hline $\mathbf{H} / \mathbf{C}$ & 0,82 & 0,76 & 0,70 \\
\hline $\mathbf{O} / \mathbf{C}$ & 0,06 & 0,04 & 0,03 \\
\hline $\mathbf{f}$ & 0,67 & 0,69 & 0,73 \\
\hline $\mathbf{c A}$ & 0,67 & 0,68 & 0,65 \\
\hline
\end{tabular}

Table 2. Chemical composition of ash of high-ash Angren brown coal

\begin{tabular}{|c|c|c|}
\hline Component name & $\begin{array}{c}\text { Unit of } \\
\text { measurement }\end{array}$ & $\begin{array}{c}\text { Numerical } \\
\text { values }\end{array}$ \\
\hline $\mathrm{Si} \mathrm{O}_{2}$ & $\%$ & $32,0 \ldots 60,6$ \\
\hline $\mathrm{Al}_{2} \mathrm{O}_{3}$ & $\%$ & $17,5 \ldots 22$ \\
\hline $\mathrm{Fe}_{2} \mathrm{O}_{3}$ & $\%$ & $3,5 \ldots 15,0$ \\
\hline $\mathrm{Ca} \mathrm{O}$ & $\%$ & $7,8 \ldots 24,2$ \\
\hline $\mathrm{Mg} \mathrm{O}$ & $\%$ & $1,0 \ldots 4,2$ \\
\hline $\mathrm{K}_{2} \mathrm{O}+\mathrm{Na}_{2} \mathrm{O}$ & $\%$ & $1,32 \ldots 4,2$ \\
\hline
\end{tabular}

According to the theory of chemical structure, the properties of substances (including the organic mass of coal) are determined by the nature of the bonds of atoms in molecules and their mutual influence. The objects of study were brown coal from the Angren deposit from three production sites: Angren - 1, Angren - 2 and Apartak. The studied elements included: carbon (C), hydrogen $(\mathrm{H})$, nitrogen $(\mathrm{N})$, silicon $(\mathrm{S})$ and oxygen $(\mathrm{O})$. The results of the study of the element-wise composition of the coals of the three mining sites are presented in Table 1. Based on the results of the study (Table 1), the atomic ratios of hydrogen and carbon $(\mathrm{H} / \mathrm{C}$ and $\mathrm{O} / \mathrm{C})$ were calculated, as well as the values of the indicators of the degree of aromaticity of the structure (fa) and the degree of molecular association of coal substances (cA), which strongly affect thermal processes (drying, burning and others):

$$
\begin{aligned}
& \mathrm{f}_{\mathrm{a}}=1,007-0,3857(\mathrm{H} / \mathrm{C})-0,3725(\mathrm{O} / \mathrm{C}) \\
& \mathrm{cA}=1-(\mathrm{H}+0,125(\mathrm{O}+\mathrm{N}+\mathrm{S})) / 0,333 \mathrm{C}
\end{aligned}
$$

$\mathrm{f}_{\mathrm{a}}$ is calculated using the atomic relations $\mathrm{H} / \mathrm{C}$ and $\mathrm{O} / \mathrm{C}$, and when calculating $\mathrm{cA}$ - weight percent $[6,7]$.The elementary composition of the samples under study was determined using a «Rapido» technical balance, a VLR200 laboratory equal-arm balance, a SNOL 8.2/1100 laboratory electric resistance furnace, and a SNOL 24/200 laboratory electric drying cabinet. According to some features (increased sulfur content, sintering capacity, carbon content), this coal could be considered as poorly reduced [8]. A number of samples (taken for research) of the "Apartak", "Angren - 1" and "Angren 2 " coals had values of the optical density D 0,$92 ; 0,54$; and 0,40 , respectively, and the calorific value $Q_{w}^{l}$ (energy value of coal), respectively, 4,2; 4,5; 5,2 MJ/kg. In fig. 1 shows a photograph of the dispersed composition of high-ash Angren brown coal [9]. Also images of the studied coal samples were taken using a polarizing microscope AXIOScope A1 from ZEISS. In fig. 2, fig. 3 and fig. 4 shows fragments of such a study. The above figures clearly show mineral impurities (noncombustible) in the form of white spots.

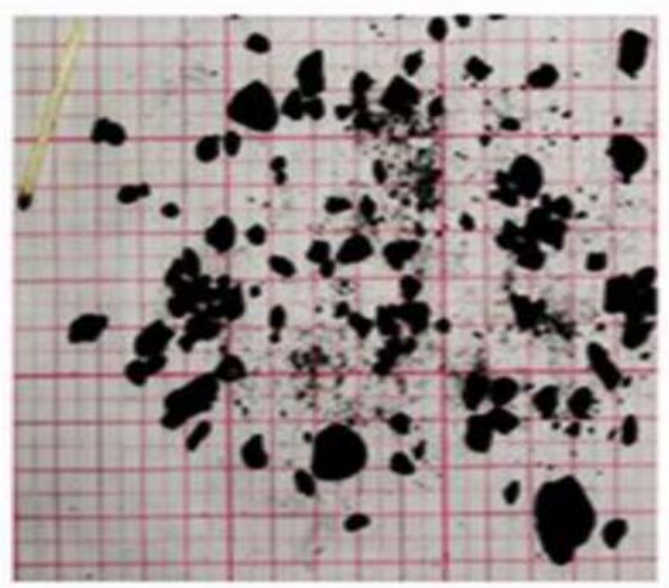

Figure: 1. A photography of the dispersed composition of high-ash Angren brown coal.

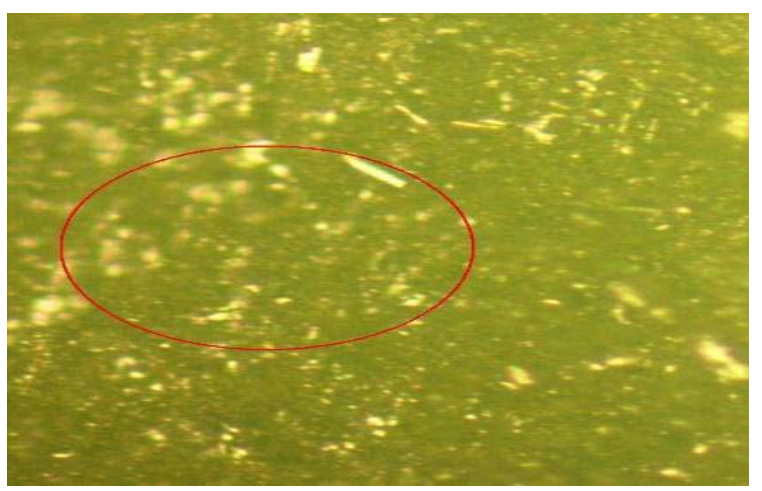

Figure: 2. Coal surface of the "Apartak" mining site at tenfold magnification on a polarizing microscope AXIOScope A1 of the German company ZEISS. 


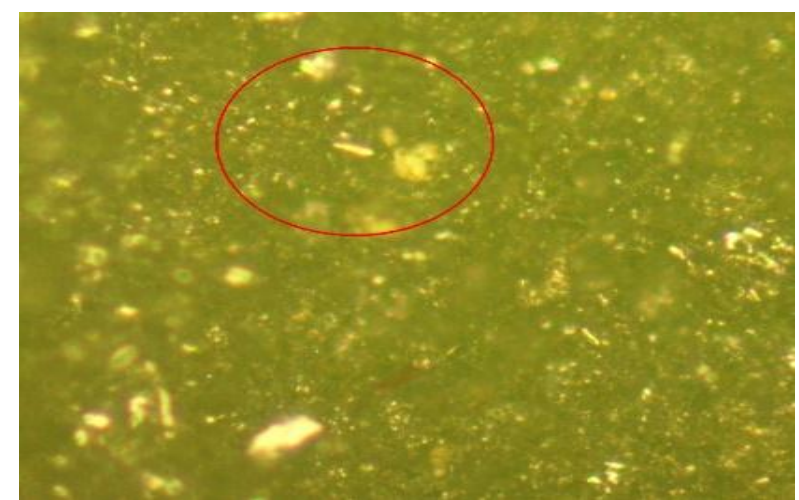

Figure: 3. Coal surface of Angren-2 mining site at tenfold magnification on a polarizing microscope AXIOScope A1 of the German company ZEISS.

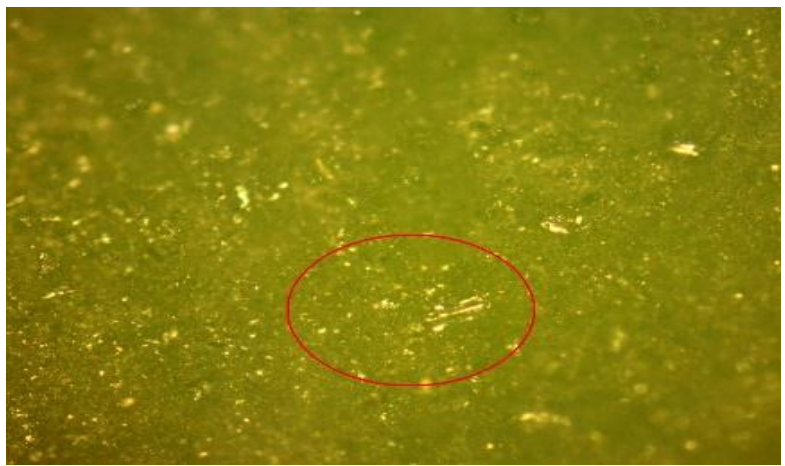

Figure: 4. Coal surface of the Angren-1 mining site at tenfold magnification on a polarizing microscope AXIOScope A1 of the German company ZEISS.

\section{Conclusion}

Analysis of the data presented in Table 1 leads to the conclusion that, in comparison with typical bituminous coal, coal from the Angren-1 mining site is characterized by reduced carbon content, noticeably higher oxygen content with an almost equal hydrogen content. Elemental analysis data and structural characteristics suggest that the specificity of the properties of Angren1 coal is due to the presence in the composition of its organic mass, along with condensed aromatic hydrocarbons (judging by the rather large values of fa and $\mathrm{cA}$ ), also significant amounts of aliphatic groups (judging by the value of the atomic ratio $\mathrm{H} / \mathrm{C}$ ) and oxygen-containing compounds: hydroxyl acids of carboxyl and hydroxyl groups and others (judging by the values of $\mathrm{O}$ and $\mathrm{O} / \mathrm{C}$ ). It can also be noted that the accompanying tertiary mineral impurities in the composition of coal, coming from the surrounding rocks during the artificial lift processes, lead to a decrease in the quality of the coal being mined. Therefore, one of the ways to improve its quality is enrichment with separation of associated impurities of rocks. This research technique makes it possible to assess the characteristics and structure of the ash content of coals from other deposits.

\section{Acknowledgments}

Laboratory studies were carried out in the scientific laboratories of the Department of Heat Power
Engineering and Nuclear Power Plants of the Tashkent State Technical University and in the Center for High Technologies of the National University of the Republic of Uzbekistan.

\section{References}

1. Z.G. Kayumov The results of studying the physical and mechanical properties of the main rocks of the lower part of the Angren coal mine. "Khabarnoma". Tech. ser. (2004) No. 1. S.28-33.

2. V.A.Volkovinsky, K.F. Roddatis, E.N. Tolchinsky Dust preparation systems with ventilator mills - M .: Energoatomizdat, (1990) -272 p.

3. M.B. Ravich Fuel and efficiency of its use. - M .: (1971)-358 p.

4. http: //processes.open mechanics.com /articles/ /161.pdf

5. http: //inethub.olvi.net.ua/ftp/library/somelibrary

6. A.S. Listopad Abstract. Study of the properties of coal from the "Krasnoarmeiskaya Zapadnaya No. 1" mine and its impact on the quality of metallurgical coke. Donetsk: DonNTU, DonNU, (2008)-- 262p.

7. The act of sampling brown coal for testing in accordance with GOST 11014-2001.p.6.4; GOST 11022-95 clause 4.2. Test date 05.02.2016

8. O.N. Fedyaeva, Yu.F. Patrakov Structure and properties of macromolecular fragments of organic matter of coal // KhTT. No. 5. (2004) S. 24-31.

9. R.P. Babakhodjaev Methods for increasing the energy efficiency of thermal power plants based on the intensification of hydrodynamic processes. Doctoral (DSc) dissertation abstract. Tashkent. TSTU. (2018)-$54 \mathrm{p}$. 